\title{
Stimulation of MC38 tumor growth by insulin analog X10 involves the serine synthesis pathway
}

\author{
Henning Hvid ${ }^{1,2}$, Sarah-Maria Fendt ${ }^{3}$, Marie-José Blouin ${ }^{1}$, Elena Birman ${ }^{1}$, \\ Gregory Voisin", Angela Manegold Svendsen ${ }^{5}$, Russell Frank ${ }^{1}$, \\ Matthew G Vander Heiden ${ }^{6}$, Gregory Stephanopoulos ${ }^{3}$, Bo Falck Hansen² \\ and Michael Pollak ${ }^{1}$
}

\footnotetext{
${ }^{1}$ Lady Davis Institute for Medical Research, Jewish General Hospital, 3755 Cote-Ste.-Catherine, Montreal, Quebec, Canada H3T 1E2

${ }^{2}$ Insulin Biology, Novo Nordisk A/S, DK-2760, Copenhagen, Denmark

${ }^{3}$ Department of Chemical Engineering, Massachusetts Institute of Technology, Cambridge, Massachusetts 02139, USA

${ }^{4}$ Genome Centre Quebec, Montreal, Quebec, Canada H3A 0G1

${ }^{5}$ Incretin Biology, Novo Nordisk A/S, DK-2760, Copenhagen, Denmark

${ }^{6}$ Koch Institute for Cancer Research, Massachusetts Institute of Technology, Cambridge, Massachusetts 02139, USA

(Correspondence should be addressed to $\mathrm{H}$ Hvid at Lady Davis Institute for Medical Research, Jewish General Hospital, 3755 Cote-Ste.-Catherine, Montreal, Quebec, Canada H3T 1E2; Email: hhvd@novonordisk.com)
}

\begin{abstract}
Recent evidence suggests that type II diabetes is associated with increased risk and/or aggressive behavior of several cancers, including those arising from the colon. Concerns have been raised that endogenous hyperinsulinemia and/or exogenous insulin and insulin analogs might stimulate proliferation of neoplastic cells. However, the mechanisms underlying possible growth-promoting effects of insulin and insulin analogs in cancer cells in vivo, such as changes in gene expression, are incompletely described. We observed that administration of the insulin analog X10 significantly increased tumor growth and proliferation in a murine colon cancer model (MC38 cell allografts). Insulin and X10 altered gene expression in MC38 tumors in a similar fashion, but X10 was more potent in terms of the number of genes influenced and the magnitude of changes in gene expression. Many of the affected genes were annotated to metabolism, nutrient uptake, and protein synthesis. Strikingly, expression of genes encoding enzymes in the serine synthesis pathway, recently shown to be critical for neoplastic proliferation, was increased following treatment with insulin and X10. Using stable isotopic tracers and mass spectrometry, we confirmed that insulin and X10 increased glucose contribution to serine synthesis in MC38 cells. The data demonstrate that the tumor growth-promoting effects of insulin and X10 are associated with changes in expression of genes involved in cellular energy metabolism and reveal previously unrecognized effects of insulin and X10 on serine synthesis.
\end{abstract}

Endocrine-Related Cancer (2012) 19 557-574

\section{Introduction}

Epidemiological studies indicate that obesity and type II diabetes are associated with an increased risk for development of certain types of cancer, including breast, colon, and pancreatic cancer (Adami et al. 1991, Calle \& Kaaks 2004, Coughlin et al. 2004, Ogunleye et al. 2009, Chen 2011). While a recent study raised the possibility that the apparent link between type II diabetes and cancer may be explained by the so-called detection bias (Carstensen et al. 2012), concerns remain that endogenous hyperinsulinemia or therapeutic use of insulin and/or insulin analogs may increase the growth of existing cancers (Smith \& Gale 2009). Effects of insulin on gene expression are well described in its classic target tissues (liver, muscle, and fat), where insulin, for example, increases expression of genes involved in glycolysis and lipogenesis and decreases expression of genes involved 
in gluconeogenesis (O'Brien \& Granner 1996, Saltiel \& Kahn 2001). However, in nonclassic target tissues, in particular cancer cells, less is known about the effects of insulin on gene expression. Importantly, the precise changes in gene expression secondary to insulin receptor (IR) activation that mediate a possible growth-promoting effect of insulin on cancer cells in vivo are not well described, even though mitogenic potential of insulin and different analogs has been examined in several studies in vitro (Milazzo et al. 1997, Kurtzhals et al. 2000, Listov-Saabye et al. 2009, Sommerfeld et al. 2010).

Mitogenic effects of insulin and insulin analogs are often considered separately from metabolic effects, with emphasis on the role of cell cycle progression and antiapoptotic mechanisms via activation of the phosphoinositide 3-kinase/Akt pathway and the RAS/RAF/MAPK pathway (Lawlor \& Alessi 2001, Jensen \& De Meyts 2009, Sciacca et al. 2010). For example, IR agonists that bind the IR and induce metabolic effects such as glycogen synthesis but only weak mitogenic effects have been described (Jensen et al. 2007). However, a growing body of evidence indicates that the model of independent metabolic and mitogenic consequences of IR activation may be too simple, as increased proliferation requires alterations in cellular metabolism (Vander Heiden et al. 2009, Locasale et al. 2011, Possemato et al. 2011). Thus, while for some tissues insulin may have minimal proliferation-stimulating effects, in those cases where insulin does favor proliferation, this is hypothesized to require a coordinated modification of metabolic processes, in order to ensure that both the energetic needs and the biosynthetic needs for cell division are met.

Previous in vivo studies revealed the rapid-acting insulin analog X10, which has increased affinity for the IR and the insulin-like growth factor 1 receptor (IGF1R) and displays decreased off-rate from the IR (Hansen et al. 1996, Slieker et al. 1997, Kurtzhals et al. 2000), increased the tumor incidence in female rats compared with native human insulin (Dideriksen et al. 1992). We therefore examined the effects of chronic treatment with insulin and the insulin analog X10 on global gene expression in colon cancer allografts. In order to model the clinical treatment of type II diabetes, we used MC38 cell allografts in mice with diet-induced obesity and hyperinsulinemia (Mashhedi et al. 2011). After treatment with insulin or X10 for 17 days, gene expression in the tumor allografts was studied using microarray technology and quantitative real-time PCR (qRT-PCR).

\section{Materials and methods}

\section{Animal experiments}

Male C57BL/6J mice were purchased from Jackson Laboratories (Bar Habor, ME, USA). At arrival, the mice were 18 weeks old and had been maintained on a high-fat diet for 12 weeks (rodent diet with $60 \mathrm{kcal} \%$ fat, Research Diets, Inc., New Brunswick, NJ, USA, cat. no. D12492). The mice were housed one mouse per cage, with ad libitum access to drinking water (tap water) and high-fat diet. The temperature in the animal room was maintained at $20-25^{\circ} \mathrm{C}$. The light/dark cycle was $14 / 10 \mathrm{~h}$. The animals were acclimatized for 10 days before the start of the experiment. At experimental day 1 , each mouse was injected subcutaneously in the right flank with $5.0 \times 10^{5} \mathrm{MC} 38$ cells suspended in $0.1 \mathrm{ml}$ PBS. Starting on experimental day 1 , each mouse was injected with either vehicle (containing $5 \mathrm{mM}$ phosphate, $140 \mathrm{mM} \mathrm{NaCl}$, and $70 \mathrm{ppm}$ polysorbate 20), recombinant native human insulin (Novo Nordisk A/S, Copenhagen, Denmark) $100 \mathrm{IU} / \mathrm{kg}(600 \mathrm{nmol} / \mathrm{kg})$, or insulin analog X10 (B10Asp; Novo Nordisk A/S) $100 \mathrm{IU} / \mathrm{kg}(600 \mathrm{nmol} / \mathrm{kg})$. Injections were thereafter administered twice daily, at $\sim 0800$ and $1800 \mathrm{~h}$. The animals were weighed at the start of the experiment and twice weekly thereafter, and doses of insulin and X10 were adjusted continuously according to bodyweight. The tumor size was measured three times per week and the tumor volume was calculated using the following formula: length $\times$ width $^{2} \times 0.52$. On experimental day 17 , the mice were treated once and killed $6 \mathrm{~h}$ after the last injection. After the animals were killed, samples of tumor allografts and colon were collected and immediately preserved in RNAlater (Qiagen, Inc.), $10 \%$ neutral buffered formalin, or snap-frozen in liquid nitrogen for subsequent analysis. In a parallel study, animals were killed at 15 min (two animals per treatment), $1 \mathrm{~h}$ (three animals per treatment), or $6 \mathrm{~h}$ (two animals per treatment) after the last treatment with vehicle, insulin, or X10. After the animals were killed, tissue samples were collected and preserved by snap freezing in liquid nitrogen.

\section{Cell culture}

MC38 cells (gift from Dr Pnina Brodt, McGill University, Montreal, QC, Canada) were plated in six-well plates and cultivated for 2 days in growth medium (DMEM medium containing $4.5 \mathrm{~g} / 1$ glucose (Wisent, Inc., Montreal, QC, Canada, cat. no. 319005)), supplemented with 10 vol\% fetal bovine serum (FBS; Invitrogen), and $20 \mu \mathrm{g} / \mathrm{ml}$ gentamicin (Sandoz 
Canada, Boucherville, QC, Canada). At day 2, the cells were $60-70 \%$ confluent and growth medium was removed, and the cells were rinsed once in PBS before starvation medium was added (DMEM medium containing $4.5 \mathrm{~g} / \mathrm{l}$ glucose but no phenol red and only 0.25 vol\% FBS). Cells were starved overnight (experiment 1 ) or for $3 \mathrm{~h}$ (experiments 2 and 3 ). We observed no difference between overnight and 3-h starvation. After the starvation period, cells were treated with native human insulin or insulin X10 at final concentrations of 1,10 , or $100 \mathrm{nM}(100 \mathrm{nM}$ only used in experiment 1). Control samples were treated with dilutions of vehicle. Experiment 1 comprised two replicates per treatment (except control; three replicates), experiments 2 and 3 comprised three replicates per treatment. Cells were harvested for mRNA isolation after treatment for 6 (experiment 1) and $24 \mathrm{~h}$ (all three experiments).

\section{Immunohistochemistry and quantification of stained cells}

Sections of $4 \mu \mathrm{m}$ were cut and mounted on SuperFrost + glass slides and dried overnight at $37^{\circ} \mathrm{C}$. Immunostaining was performed using a Discovery XT Autostainer (Ventana Medical Systems, Inc., Tucson, AZ, USA). Briefly, slides were deparaffinized and rehydrated before heat-induced epitope retrieval was performed at $\mathrm{pH} 6.0$ in RiboCC buffer (Ventana). Slides were then blocked using inhibitor CM solution (Ventana) and thereafter incubated for $30 \mathrm{~min}$ with primary antibody monoclonal rabbit antiphoshorylated histone H3 (P-H3; Ser10; Cell Signaling Technology, Boston, MA, USA, cat. no. 3377) at $0.04 \mu \mathrm{g} / \mathrm{ml}$, and afterwards with HRP-conjugated Omnimap antirabbit multimer (Ventana). DAB was used as chromogen and hematoxylin was used for counterstaining before mounting of cover glasses. Staining of colon was used as an internal positive control, and negative controls included omission of the primary antibody and substitution of the primary antibody with an isotypematched negative control antibody.

Cells stained positively for $\mathrm{P}-\mathrm{H} 3$ were quantified using a Leica DM LB2 microscope (Leica Camera, Inc., Allendale, NJ, USA) equipped with a Leica DFC 480 digital camera (Leica Camera, Inc.), and the software Image J (NIH, Bethesda, MD, USA). In each tumor section, ten pictures were captured in randomized positions along the tumor edge at $400 \times$ magnification. Subsequently, primary and secondary counting frames were superimposed on each picture. In the primary counting frame all cells were counted, in the secondary counting frame only positively stained cells were counted. The area of the secondary counting frame was $6 \%$ of the area of the primary counting frame, so it was possible to obtain an approximate equal and sufficient number of counts as recommended previously (Gundersen et al. 1988). The counts were adjusted for the different sizes of the counting frames, and the percentage of positively stained cells was calculated.

In the colon, the number of positively stained cells was quantified per crypt. In each section, the total number of cells and the number of positive cells were counted in all crypts visible in the entire length. In each animal, 20-25 crypts were counted, and based on this mean crypt size and percentage of positively stained cells were calculated per animal.

\section{Preparation of tissue lysates and western blotting}

Frozen tumor and colon samples were lyzed in cell extraction buffer $(50 \mathrm{mM}$ HEPES, $1 \%$ Triton-X 100, $150 \mathrm{mM} \mathrm{NaCl}, 0.02 \%$ sodium azide, $60 \mathrm{mM}$ $\beta$-glycerophosphate, and $1 \mathrm{mM}$ dithiothreitol) containing protease and phosphatase inhibitor cocktails (Roche), using an Omni TH tissue homogenizer (Omni International, Kennesaw, GA, USA). Lysates were cleared by centrifugation at $4500 \mathrm{~g}$ at $4{ }^{\circ} \mathrm{C}$. Protein concentration was measured by the BCA method according to manufacturer's instructions (Thermo Scientific, Nepean, ON, Canada). Lysate was mixed with $2 \times$ SDS sample buffer (containing $130 \mathrm{mM}$ Tris, $2 \%$ SDS, $1 \% \beta$-mercaptoethanol, $0.08 \%$ bromophenol blue, and $20 \%$ glycerol) and denaturized by heating at $90{ }^{\circ} \mathrm{C}$ for $5 \mathrm{~min}$. SDS-PAGE with $20 \mu \mathrm{g}$ total protein per sample was performed on precast $4-15 \%$ gradient gels (Bio-Rad) at $135 \mathrm{~V}$ for $1 \mathrm{~h}$, and proteins were transferred to $0.45 \mu \mathrm{m}$ nitrocellulose membranes (BioRad) in a transfer buffer containing $15 \mathrm{mM}$ Tris, $120 \mathrm{mM}$ glycine, and $20 \mathrm{vol} \%$ methanol. The nitrocellulose membranes were blocked for $1 \mathrm{~h}$ in Tris-buffered saline with $0.05 \%$ tween (TBS-T) containing 5\% BSA, washed in TBS-T for $3 \times 5 \mathrm{~min}$, and incubated with primary antibody diluted in TBS-T with $5 \%$ BSA overnight at $4{ }^{\circ} \mathrm{C}$. The primary antibody was polyclonal rabbit antiphosphorylated Akt (Ser473; Cell Signaling Technology, cat. no. 9271). The following day the membranes were washed $3 \times 5 \mathrm{~min}$ in TBS-T and incubated for $1 \mathrm{~h}$ at room temperature using HRP-conjugated goat antirabbit IgG (Santa Cruz Biotechnology, Santa Cruz, CA, USA, cat. no. 5401) diluted 1:10 000 in TBS-T with 5\% skim milk. Finally, the membranes were washed for $3 \times 5 \mathrm{~min}$ in TBS-T, and protein bands were visualized using SuperSignal 
Table 1 Genes up- or downregulated $\geq 1.5$-fold after treatment with insulin or X10

\begin{tabular}{|c|c|c|c|}
\hline \multirow[b]{2}{*}{ Gene symbol } & \multirow[b]{2}{*}{ Entrez gene name } & \multicolumn{2}{|c|}{ Fold change } \\
\hline & & Insulin & $\mathbf{X} 10$ \\
\hline \multicolumn{4}{|l|}{ Metabolism } \\
\hline Adh7 & Alcohol dehydrogenase 7 (class IV), $\mu$ - or $\sigma$-polypeptide & 1.421 & 1.569 \\
\hline Aldh18a1 & Aldehyde dehydrogenase 18 family, member $A 1$ & 1.279 & 1.790 \\
\hline Aldh1/2 & Aldehyde dehydrogenase 1 family, member L2 & 1.814 & 1.769 \\
\hline Asns & Asparagine synthetase (glutamine-hydrolyzing) & 1.658 & 1.693 \\
\hline Chchd10 & Coiled-coil-helix-coiled-coil-helix domain containing 10 & NCD & -1.565 \\
\hline Cyb5r1 & Cytochrome b5 reductase 1 & 1.674 & 1.950 \\
\hline Cyp51a1 & Cytochrome P450, family 51 , subfamily A, polypeptide 1 & 1.287 & 1.536 \\
\hline Fdps & Farnesyl diphosphate synthase & 1.478 & 1.614 \\
\hline Gpt2 & Glutamic pyruvate transaminase (alanine aminotransferase) 2 & 1.652 & 1.908 \\
\hline Nup210 & Nucleoporin $210 \mathrm{kDa}$ & -1.230 & -1.518 \\
\hline Phgdh & Phosphoglycerate dehydrogenase & 1.550 & 1.584 \\
\hline Psat1 & Phosphoserine aminotransferase 1 & 1.432 & 1.602 \\
\hline Shmt2 & Serine hydroxymethyltransferase 2 (mitochondrial) & 1.534 & 1.502 \\
\hline Gm7669 & 3-Phosphoglycerate dehydrogenase pseudogene & 1.594 & 1.704 \\
\hline Gm7901 & 3-Phosphoglycerate dehydrogenase pseudogene & 1.387 & 1.599 \\
\hline Gm8163 & Farnesyl diphosphate synthase pseudogene & 1.651 & 1.736 \\
\hline Hk2 & Hexokinase 2 & 1.493 & 1.557 \\
\hline \multicolumn{4}{|c|}{ DNA replication, transcription, and RNA translation } \\
\hline Dbp & D site of albumin promoter (albumin D-box) binding protein & -1.516 & -1.345 \\
\hline Lars & Leucyl-tRNA synthetase & 1.408 & 1.593 \\
\hline Lonp1 & Ion peptidase 1 , mitochondrial & 1.632 & 1.734 \\
\hline Nars & Asparaginyl-tRNA synthetase & 1.431 & 1.645 \\
\hline Ruvbl2 & RuvB-like 2 (E. coli) & 1.319 & 1.510 \\
\hline Sars & Seryl-tRNA synthetase & 1.475 & 1.546 \\
\hline Nop56 & NOP56 ribonucleoprotein homolog (yeast) & 1.505 & 1.548 \\
\hline Phf10 & PHD finger protein 10 & 1.506 & 1.500 \\
\hline Srebf2 & Sterol regulatory element binding transcription factor 2 & 1.287 & 1.513 \\
\hline Loc674706 & Synonym: similar to zinc finger protein 341 & 1.712 & NCD \\
\hline Loc100048076 & Synonym: similar to MAD homolog 4 (Drosophila) & -1.197 & -1.518 \\
\hline \multicolumn{4}{|c|}{ Transmembrane transport } \\
\hline Slc1a4 & Solute carrier family 1 (glutamate/neutral amino acid transporter), member 4 & NCD & 1.526 \\
\hline Slc25a33 & Solute carrier family 25 , member 33 & 1.480 & 1.720 \\
\hline Loc100047619 & $\begin{array}{l}\text { Synonym: similar to solute carrier family } 7 \text { (cationic amino acid transporter, } \\
\text { y+ system, member } 5 \text {, pseudogene }\end{array}$ & 1.495 & 1.646 \\
\hline \multicolumn{4}{|c|}{ 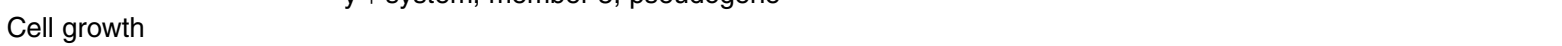 } \\
\hline Grem1 & Gremlin 1 & 1.967 & 1.910 \\
\hline Hist1h1c & Histone cluster $1, \mathrm{H} 1 \mathrm{c}$ & -1.242 & -1.713 \\
\hline Ptpn18 & Protein tyrosine phosphatase, nonreceptor type 18 (brain-derived) & -1.326 & -1.569 \\
\hline Sema4a & $\begin{array}{l}\text { Sema domain, immunoglobulin domain (Ig), transmembrane domain, } \\
\text { and short cytoplasmic domain (semaphorin) } 4 \mathrm{~A}\end{array}$ & NCD & -1.582 \\
\hline Tmem86a & Transmembrane protein $86 \mathrm{~A}$ & -1.480 & -1.818 \\
\hline Tmem97 & Transmembrane protein 97 & 1.297 & 1.613 \\
\hline \multicolumn{4}{|l|}{ Proliferation } \\
\hline Angpt/6 & Angiopoietin-like 6 & 1.773 & 1.873 \\
\hline Plk2 & Polo-like kinase 2 & 1.176 & 1.541 \\
\hline \multicolumn{4}{|l|}{ Apoptosis } \\
\hline Ddit3 & DNA-damage-inducible transcript 3 & 1.396 & 2.027 \\
\hline Ddit4 & DNA-damage-inducible transcript 4 & 1.355 & 1.557 \\
\hline Trib3 & Tribbles homolog 3 (Drosophila) & 1.329 & 2.055 \\
\hline Chac1 & ChaC, cation transport regulator homolog 1 (E. coli) & NCD & 1.995 \\
\hline Tfrc & Transferrin receptor (p90, CD71) & NCD & 1.589 \\
\hline Rnf130 & Ring finger protein 130 & -1.265 & -1.575 \\
\hline Ypel3 & Yippee-like 3 (Drosophila) & -1.356 & -1.662 \\
\hline Ppp1r15a & Protein phosphatase 1 regulatory subunit 15A (PPP1R15A) & 1.289 & 1.991 \\
\hline
\end{tabular}




\begin{tabular}{|c|c|c|c|}
\hline \multirow[b]{2}{*}{ Gene symbol } & \multirow[b]{2}{*}{ Entrez gene name } & \multicolumn{2}{|c|}{ Fold change } \\
\hline & & Insulin & $\mathbf{x} 10$ \\
\hline \multicolumn{4}{|c|}{ Other functions or unknown function } \\
\hline Cd6 & CD6 molecule & -1.352 & -1.540 \\
\hline Cdr2l & Cerebellar degeneration-related protein 2-like & 1.209 & 1.611 \\
\hline Cfp & Complement factor properdin & -1.264 & -1.624 \\
\hline Chmp4b & Charged multivesicular body protein 4B & 1.867 & 1.304 \\
\hline Ctsw & Cathepsin W & -1.526 & -1.556 \\
\hline Cytip & Cytohesin 1 interacting protein & -1.241 & -1.506 \\
\hline KIrd1 & Killer cell lectin-like receptor subfamily D, member 1 & -1.405 & -1.626 \\
\hline Mrgprf & MAS-related GPR, member F & -1.674 & -1.335 \\
\hline C3 & Complement component 3 & NCD & -1.608 \\
\hline Napsa & Napsin A aspartic peptidase & -1.266 & -1.667 \\
\hline$N k g 7$ & Natural killer cell group 7 sequence & -1.606 & -1.615 \\
\hline Prkg2 & Protein kinase, cGMP-dependent, type II & 1.757 & 1.637 \\
\hline Selplg & Selectin P ligand & -1.427 & -1.536 \\
\hline Sh2d2a & $\mathrm{SH} 2$ domain containing $2 \mathrm{~A}$ & -1.463 & -1.658 \\
\hline Steap1 & Six transmembrane epithelial antigen of the prostate 1 & 1.615 & 1.798 \\
\hline Irgm2 & Immunity-related GTPase family M member 2 & NCD & -1.582 \\
\hline Ccl8 & Synonym: chemokine (C-C motif) ligand 8, CCL8 & NCD & -2.246 \\
\hline 5430416N02Rik & RIKEN cDNA 5430416N02 & 1.528 & 1.922 \\
\hline H2-ab1 & Histocompatibility 2 , antigen $A$, beta 1 & -1.298 & -1.658 \\
\hline
\end{tabular}

NCD, no significant change detected; ND, not detected.

West Pico Luminescent Substrate (Thermo Scientific) and a ChemiDoc MP Imaging System (Bio-Rad).

\section{Isolation of RNA and cDNA synthesis}

Tissue samples preserved in RNAlater were first homogenized using an Omni TH tissue homogenizer (Omni International), and afterward total RNA was extracted using the RNeasy Plus mini kit according to manufacturer's instructions (Qiagen, Inc.). For all RNA samples, the concentration quality and integrity were assessed using a NanoDrop spectrophotometer and an Agilent 2100 Bioanalyzer (Agilent Technologies, Mississauga, ON, Canada). All samples were of high quality. For the synthesis of cDNA, 900 ng RNA were reverse transcribed using the iScript cDNA kit (Bio-Rad). Finally, the concentration of cDNA was measured using the Oligreen ssDNA Quantitation kit (Invitrogen) as described previously (Lundby et al. 2005).

\section{Microarrays}

Reverse transcription of RNA, biotin-labeling, hybridization to Illumina MouseWG-6 v2 beadchips, and scanning with iScan reader were performed according to manufacturer's recommendations (Illumina, Inc., San Diego, CA, USA). Analysis of the Illumina MouseWG-6 beadchip gene expression data was done using the software FlexArray (developed by Michael Blazejczyk and Genome Quebec). Raw data were imported into FlexArray and normalized using the Lumi Bioconductor package algorithms, which includes variance stabilizing transformation and robust spline normalization (Du et al. 2008, Lin et al. 2008). Quality control of the normalized data was performed as described in the Lumi package. To identify genes regulated by insulin and X10, an ANOVA was performed between the experimental conditions vehicle, insulin and X10, each represented by three biological replicates (animals). Expression changes with $P$ value $<0.05$ were considered significant. Based on these selected transcripts, we thereafter performed three modified $t$-tests (Baldi and Long cyber $t$-test; Baldi \& Long 2001) to identify between which conditions the expression differences were found, i.e. we compared insulin with vehicle, X10 with vehicle, and insulin with X10. The results of each cyber $t$-test were adjusted for multiple comparisons using the false discovery rate algorithm with Benjamini-Hochberg correction (Benjamini \& Hochberg 1995). Transcripts with an adjusted $P$ value $<0.05$ were defined as differentially expressed. By this approach, three groups of transcripts were identified: transcripts with a significant change in expression in insulin-treated animals compared with control, transcripts with a significant change in expression in X10-treated 
animals compared with control, and transcripts expressed at significantly different levels between insulin- and X10-treated animals. These groups comprised all transcripts identified as differentially expressed, irrespective of fold change, and in the further analysis we applied cutoff values for the definition of differentially expressed transcripts of $\geq 1.3$ - and $\geq 1.5$-fold change in expression, which have been used in previous studies (Peart et al. 2005, Huggins et al. 2008, Raouf et al. 2008).

The analysis was performed using the raw probe data and probe data translated into transcripts (Illumina beadchips contain multiple probes for each transcript). Furthermore, the analysis was performed with and without exclusion of transcripts not detected in the tumor allograft samples. As a supplementary analysis, we also performed a direct comparison of insulin vs vehicle and X10 vs vehicle, respectively, in a cyber $t$-test without performing an initial ANOVA.

With FlexArray, we analyzed the number of transcripts where the expression changed following treatment with insulin or X10 using the different cutoff values for definition of differentially expressed transcripts. Subsequently, annotation and functional analyses of transcripts regulated by insulin and X10 were done using Ingenuity Pathway Analysis (IPA; Ingenuity Systems, www.ingenuity.com).
All transcripts influenced by insulin and/or X10 are shown in Supplementary Tables 1, 2 and 3, see section on supplementary data given at the end of this article. To identify the major functions affected by insulin and $\mathrm{X} 10$, we first studied the annotations of each transcript displaying $\geq 1.5$-fold change in expression and then manually assigned the transcripts to functional groups (Table 1). Next, we examined the results of functional analysis, in which the biological functions that were most significant to the dataset were identified (Table 2). All transcripts with significantly changed expression, met the $\geq 1.3$ - and $\geq 1.5$-fold expression change cut off, and were associated with biological functions in the Ingenuity Knowledge Base were considered for the analyses. Right-tailed Fisher's exact test was used to calculate a $P$ value determining the probability that each biological function assigned to that dataset was due to chance alone.

Canonical pathway analysis identified the pathways from the IPA library that were most significant to the dataset (Table 2). Transcripts that met the selection criteria (significant change in expression, $\geq 1.3$ - and $\geq 1.5$-fold change in expression respectively) and were associated with a canonical pathway in the Ingenuity Knowledge Base were considered for the analyses. Fisher's exact test was used to calculate a $P$ value determining the probability that the association

Table 2 Molecular and cellular functions and canonical pathways for genes with $\geq 1.5$-fold change in expression

Molecular and cellular functions

Genes regulated by insulin

Amino acid metabolism

Small molecule biochemistry

Cell death

Cellular development

Cellular function and maintenance

Genes regulated by $X 10$

Amino acid metabolism

Small molecule biochemistry

Cell morphology

Cellular function and maintenance

Lipid metabolism
Significance

Number of genes

$\begin{array}{lr}3.33 \times 10^{-5} \text { to } 1.55 \times 10^{-2} & 3 \\ 3.33 \times 10^{-5} \text { to } 2.31 \times 10^{-2} & 5 \\ 1.30 \times 10^{-2} \text { to } 7.77 \times 10^{-3} & 2 \\ 1.30 \times 10^{-2} \text { to } 3.07 \times 10^{-2} & 3 \\ 2.60 \times 10^{-2} \text { to } 4.82 \times 10^{-2} & 1 \\ & \\ 3.69 \times 10^{-5} \text { to } 3.91 \times 10^{-2} & 5 \\ 3.69 \times 10^{-5} \text { to } 3.91 \times 10^{-2} & 15 \\ 1.60 \times 10^{-4} \text { to } 9.92 \times 10^{-3} & 3 \\ 1.60 \times 10^{-4} \text { to } 2.95 \times 10^{-2} & 4 \\ 5.66 \times 10^{-4} \text { to } 3.59 \times 10^{-2} & 8\end{array}$

Top canonical pathways

Genes regulated by insulin

Alanine and aspartate metabolism

Glycine, serine, and threonine metabolism

Cyanoamino acid metabolism

Methane metabolism

One carbon pool by folate

Genes regulated by $X 10$

Glycine, serine, and threonine metabolism

Aminoacyl-tRNA biosynthesis

Alanine and aspartate metabolism

Role of lipids/lipid rafts in the pathogenesis of influenza

Valine, leucine, and isoleucine biosynthesis

$1.03 \times 10^{-3}$
$3.16 \times 10^{-3}$
$1.80 \times 10^{-2}$
$2.06 \times 10^{-2}$
$2.19 \times 10^{-2}$
$6.20 \times 10^{-5}$
$2.08 \times 10^{-4}$
$2.46 \times 10^{-4}$
$2.95 \times 10^{-2}$
$3.59 \times 10^{-2}$

2

2

1

1

1

4

3

3

1

1 
between the genes in the dataset and the canonical pathway was explained by chance alone. Finally, we selected a subset of the genes from the group of genes displaying the largest fold changes in expression and representing the top five functions and canonical pathways for validation by qRT-PCR (Table 3).

\section{Quantitative real-time PCR}

The $15 \mu \mathrm{l}$ PCRs contained $1.5 \mu \mathrm{l}$ cDNA template, $0.75 \mu \mathrm{l} 20 \times$ TaqMan Gene Expression Assay (see Table 4 for specific assays, all from AB Applied Biosystems, Burlington, ON, Canada), $7.5 \mu \mathrm{l} 2 \times$ TaqMan Fast AdvanceMaster Mix (AB Applied Biosystems), and $5.25 \mu \mathrm{l}$ nuclease-free water. For Ccng2, the $15 \mu \mathrm{l}$ PCRs contained $1.5 \mu \mathrm{l}$ cDNA template, $7.5 \mu \mathrm{l} 2 \times$ Fast start TaqMan Probe Master Mix (Rox; Roche), $100 \mathrm{nM}$ universal probe number 55 (Roche, cat. no. 04688520001), and $90 \mu \mathrm{M}$ forward and reverse primers (Table 4). cDNA samples were analyzed in triplicate and no template controls with water instead of cDNA template were included in all runs. Thermal cycling was done using an Applied Biosystems 7500 Fast Real-Time PCR System instrument (AB Applied Biosystems) using the following conditions: $95^{\circ} \mathrm{C}$ for $20 \mathrm{~s}$ and thereafter 40 cycles of $95^{\circ} \mathrm{C}$ for $3 \mathrm{~s}$ and $60{ }^{\circ} \mathrm{C}$ for $30 \mathrm{~s}$. For Ccng2, the following conditions were used: $50{ }^{\circ} \mathrm{C}$ for $2 \mathrm{~min}, 95^{\circ} \mathrm{C}$ for $10 \mathrm{~min}$, and thereafter 40 cycles of $95^{\circ} \mathrm{C}$ for $15 \mathrm{~s}$ and $60{ }^{\circ} \mathrm{C}$ for $1 \mathrm{~min}$.

Quantification of target gene mRNA levels in a sample was done relative to the sample with maximum

Table 3 Confirmation of microarray results with qRT-PCR

\begin{tabular}{|c|c|c|c|c|c|c|c|}
\hline \multirow[b]{3}{*}{ Gene symbol } & \multirow[b]{3}{*}{ Entrez gene name } & \multicolumn{4}{|c|}{ MC38 cell allograft } & \multirow{2}{*}{\multicolumn{2}{|c|}{$\begin{array}{c}\text { Colon } \\
\text { Mean fold change } \\
\text { determined with } \\
\text { qRT-PCR }(n=6)\end{array}$}} \\
\hline & & \multicolumn{2}{|c|}{$\begin{array}{c}\text { Fold change } \\
\text { determined with } \\
\text { microarrays }(n=3)\end{array}$} & \multicolumn{2}{|c|}{$\begin{array}{l}\text { Mean fold change } \\
\text { determined with } \\
\text { qRT-PCR }(n=6)\end{array}$} & & \\
\hline & & Insulin & $\mathbf{X} 10$ & Insulin & $\mathbf{X} 10$ & Insulin & $\mathbf{X} 10$ \\
\hline Phgdh & Phosphoglycerate dehydrogenase & 1.55 & 1.60 & 1.32 (NS) & 1.45 (NS) & 0.83 (NS) & 0.90 (NS) \\
\hline Gm7669 & $\begin{array}{l}\text { 3-Phosphoglycerate dehydro- } \\
\text { genase pseudogene }\end{array}$ & 1.60 & 1.70 & - & - & - & - \\
\hline Gm7901 & $\begin{array}{l}\text { 3-Phosphoglycerate dehydro- } \\
\text { genase pseudogene }\end{array}$ & 1.39 & 1.60 & - & - & - & - \\
\hline Psat1 & Phosphoserine aminotransferase & 1.43 & 1.60 & $1.56^{*}$ & $1.63^{*}$ & - & - \\
\hline Shmt2 & $\begin{array}{l}\text { Serine hydroxymethyl transferase } \\
\text { (mitochondrial) }\end{array}$ & 1.53 & 1.50 & 1.39 (NS) & $1.61^{*}$ & - & - \\
\hline Gpt2 & $\begin{array}{l}\text { Glutamic pyruvate transaminase } \\
\text { (alanine aminotransferase) } 2\end{array}$ & 1.65 & 1.91 & 1.67 (NS) & $2.25^{\dagger}$ & 0.99 (NS) & 0.91 (NS) \\
\hline Asns & $\begin{array}{l}\text { Asparagine synthase (glutamine- } \\
\text { hydrolyzing) }\end{array}$ & 1.66 & 1.69 & $1.78^{*}$ & $2.09^{\dagger}$ & 1.19 (NS) & $1.31(\mathrm{NS})$ \\
\hline$P f k l^{\mathrm{a}}$ & Phosphofructokinase, liver & 1.52 & NCD & 1.42 (NS) & 1.84 (NS) & 0.89 (NS) & $0.84(\mathrm{NS})$ \\
\hline Slc2a $1^{a}$ & $\begin{array}{l}\text { Solute carrier family } 2 \text { (facilitated } \\
\text { glucose transporter), member } 1\end{array}$ & 1.64 & NCD & 1.36 (NS) & $2.40^{*}$ & 0.81 (NS) & 0.86 (NS) \\
\hline Slc1a4 & $\begin{array}{l}\text { Solute carrier family } 1 \text { (glutamate/ } \\
\text { neutral amino acid transporter) } \\
\text { member } 4\end{array}$ & NCD & 1.53 & 1.07 (NS) & $1.51^{\star}$ & 0.75 (NS) & 0.95 (NS) \\
\hline Slc6a9 ${ }^{b}$ & $\begin{array}{l}\text { Solute carrier family } 6 \text { (neurotrans- } \\
\text { mitter transporter, glycine), } \\
\text { member } 9\end{array}$ & 1.69 & 1.69 & 1.50 (NS) & $1.95^{\star}$ & 0.80 (NS) & 0.78 (NS) \\
\hline Loc100047619 & $\begin{array}{l}\text { Synonym: similar to solute carrier } \\
\text { family } 7 \text { (cationic amino acid } \\
\text { transporter, y+ system), } \\
\text { member } 5, \text { pseudogene }\end{array}$ & 1.49 & 1.65 & - & - & - & - \\
\hline Slc7a5 & $\begin{array}{l}\text { Solute carrier family } 7 \text { (cationic } \\
\text { amino acid transporter, } \\
\text { y+ system), member } 5\end{array}$ & ND & ND & 1.55 (NS) & $1.71^{*}$ & 0.80 (NS) & 1.00 (NS) \\
\hline Slc25a33 & Solute carrier family 25 member 33 & 1.48 & 1.72 & 1.21 (NS) & $1.70^{*}$ & - & - \\
\hline Ccng2 & Cyclin G2 & NCD & NCD & 1.19 (NS) & 1.07 (NS) & 1.02 (NS) & 1.15 (NS) \\
\hline
\end{tabular}

NCD, no significant change detected; ND, not detected; -, not measured; NS, not significantly changed. ${ }^{*} P<0.05$ and ${ }^{\dagger} P<0.001$. ${ }^{a}$ Only detected in direct $t$-test with filtered microarray dataset.

${ }^{b}$ Only detected in nonfiltered microarray dataset. 
H Hvid et al.: Insulin $X 10$ and the serine synthesis pathway

Table 4 Taqman gene-expression assays, primer, and probe set used for validation of microarray data using qRT-PCR

\begin{tabular}{lll}
\hline Gene & Assay ID & Product size (nt) \\
\hline Phgdh & Mm01623589_g1 & 73 \\
Psat1 & Mm01613327_g1 & 107 \\
Shmt2 & Mm00659512_g1 & 98 \\
Gpt2 & Mm00558028_m1 & 93 \\
Asns & Mm00803785_m1 & 109 \\
Pfkl & Mm00435587_m1 & 94 \\
Slc2a1 & Mm00441473_m1 & 62 \\
Slc1a4 & Mm00444532_m1 & 75 \\
Slc6a9 & Mm00433662_m1 & 75 \\
Slc7a5 & Mm00441516_m1 & 92 \\
Slc25a33 & Mm00510425_m1 & 71 \\
& Primers & Universal probe no. \\
Ccng2 & F: ggttgcttgacggaagtg & 55 (cat. no. 04688520001) \\
\hline
\end{tabular}

nt, nucleotides; F, forward primer; $\mathrm{R}$, reverse primer.

expression using the $\Delta C_{\mathrm{t}}$ method and thereafter normalized to the relative cDNA concentration as described recently (Hvid et al. 2011). Finally, expression levels were expressed relative to the average in vehicle-treated animals (in vivo experiment) or vehicle-treated cells (in vitro experiments). For calculation of expression of target genes in tumor tissue relative to colon samples, relative expression levels in tumor samples were expressed relative to the average relative expression values in colon samples.

\section{Carbon contribution to the serine synthesis pathway}

MC38 were cultured as described earlier, except that glucose was replaced with equimolar $\mathrm{U}-{ }^{13} \mathrm{C}$-labeled glucose (Cambridge Isotopes Laboratories, Andover, MA, USA). Labeled MC38 cells were washed with isotonic saline and cellular metabolism was quenched with $-20^{\circ} \mathrm{C}$ cold $65 \%$ methanol. After cell scraping in $65 \%$ methanol, $-20{ }^{\circ} \mathrm{C}$ cold chloroform was added and the samples were vortexed at $4{ }^{\circ} \mathrm{C}$ to extract metabolites. Phase separation was achieved by centrifugation at $4{ }^{\circ} \mathrm{C}$. Methanol phase (containing amino acids) was separated and dried applying constant airflow. Dried metabolite samples were stored at $-80^{\circ} \mathrm{C}$. Metabolite samples were derivatized with metoxamine (Thermo Scientific) for $90 \mathrm{~min}$ at $40{ }^{\circ} \mathrm{C}$ and subsequently with $\mathrm{N}$-(tert-butyldimethylsilyl)- $\mathrm{N}$ methyltrifluoroacetamide, with $1 \%$ tert-butyldimethylchlorosilane (Sigma-Aldrich) for $60 \mathrm{~min}$ at $60{ }^{\circ} \mathrm{C}$. Isotopomer distributions of metabolites were measured with a 6890N GC system (Agilent Technologies) combined with a 5975B Inert XL MS system (Agilent Technologies).
Isotopomer distributions were analyzed using the Matlab-based software Metran (Antoniewicz et al. 2007). Total contribution of carbon (TCC) was calculated using the following equation:

$\mathrm{TCC}=\frac{\sum_{\mathrm{i}=0}^{\mathrm{n}} \mathrm{i} \times \mathrm{m}_{\mathrm{i}}}{\mathrm{n} \times \sum_{\mathrm{i}=0}^{\mathrm{n}} \mathrm{m}_{\mathrm{i}}}$

Thereby $n$ gives the number of carbon atoms in the metabolite, $i$ the different mass isotopomers, and $m$ the abundance of a certain mass (Nanchen et al. 2007).

\section{Statistical analysis}

Statistical analysis was performed using SAS software version 9.1.3 (SAS Institute, Inc., Cary, NC, USA). In all analyses, observations were assumed to be independent among animals. Assumptions of normal distribution and variance homogeneity among data were assessed using Shapiro-Wilks test of normality and by examination of standardized residuals plotted against normal quantiles and predicted values.

Tumor volume data, tumor and colon proliferation data, gene expression data measured using qRT-PCR from tumor and colon, and percentage of serine and glycine generated from glucose were analyzed individually for each outcome using a general linear model (proc $\mathrm{glm}$ ) in SAS followed by pairwise comparisons of vehicle- and insulin-treated groups and vehicle- and X10-treated groups, respectively, using multiple $t$-tests with Dunnett's correction. For the analysis of the difference in expression level of selected genes between tumor and colon in vehicle-treated animals a single uncorrected $t$-test was carried out. To obtain normal distribution and variance homogeneity data were transformed using the natural logarithm when 


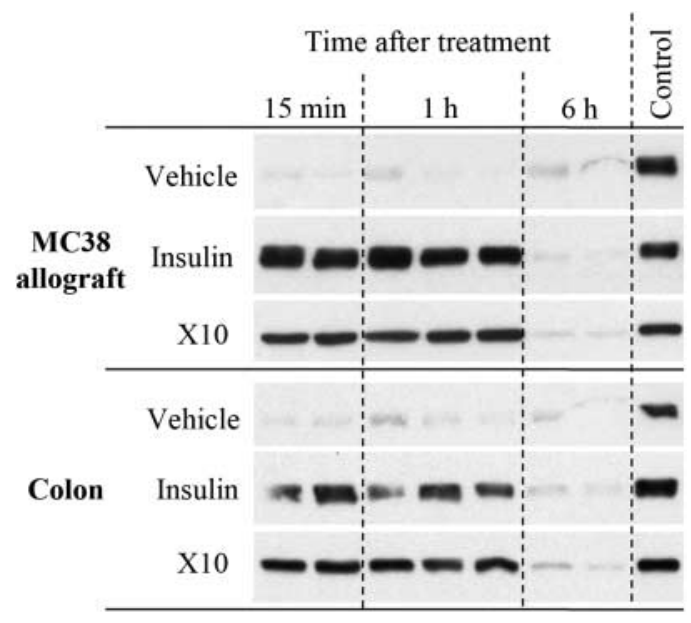

Figure 1 Western blotting for P-Akt (Ser473) in lysates prepared from MC38 allografts and colon collected at different time points after s.c. injection of vehicle, insulin, or X10 (100 IU/kg). Each band represents one animal. To allow for comparison between gel lysate from a sample of MC38 cells treated with insulin was included on all gels (lane labeled 'control').

necessary. Outliers were defined as data with a numerical standardized residual value $>3.0$ as described previously (Bibby et al. 2004), and one outlier was removed from the analysis of the tumor volume data. Gene expression data for target genes Phgdh, Pfkl, Gpt2, and Slc2al from three independent in vitro experiments were pooled and analyzed using an identical procedure. In the analysis of Phgdh and Pfkl expressions in vitro, two outliers out of 40 observations were removed to fulfill the assumptions behind the analysis. The Pearson's correlation coefficient between the percentages of serine and glycine generated from glucose was calculated using the correlation procedure in SAS (proc corr).

\section{Results}

\section{Treatment with insulin and X10 activates Akt in tumor allografts and colon}

Treatment of mice with insulin or X10 by s.c. injection resulted in rapid phosphorylation of Akt, involved in regulation of metabolism, at serine residue 473 in tumor allografts and normal colon (Fig. 1), thereby demonstrating that these nonclassic target tissues of insulin are also insulin responsive. However, the activation of Akt was transient and $6 \mathrm{~h}$ after treatment, phosphorylation of Akt had returned to basal level in both tumors and colon, which is in agreement with the relatively short half-life of insulin and X10 after s.c. injection.

\section{Insulin analog X10 increases tumor growth and proliferation}

Tumor volume in animals treated with X10 was significantly increased compared with vehicle-treated animals at day $14(P=0.0462)$ and day $17(P=0.0375$, Fig. 2). The tumor volumes in animals treated with insulin were not significantly different from animals treated with X10 or vehicle, but a trend toward an intermediate growth rate between X10 and vehicle was observed. In agreement with the tumor growth data, the mitotic index, calculated based on the percentage of PH3-labeled cells, was significantly higher in tumor tissue from animals treated with X10 than vehicle $(P=0.0131$, Fig. 3A).

No significant change was observed between animals treated with insulin or vehicle, and the percentage of labeled cells was intermediate between vehicle- and X10-treated animals. In normal colon, the percentage of $\mathrm{P}-\mathrm{H} 3$-positive epithelial cells was significantly decreased for animals treated with insulin $(P=0.0001)$ and $\mathrm{X} 10(P=0.0004)$ compared with vehicle-treated animals (Fig. 3B). The number of epithelial cells per colon crypt was not significantly different between the different groups (not shown), suggesting that insulin and X10 changed the proliferative activity of the colonic epithelial cells, but did not induce hypoplasia.

\section{X10 influence expression of more transcripts than insulin}

In total, expression of 585 transcripts was significantly changed from baseline levels in tumors of

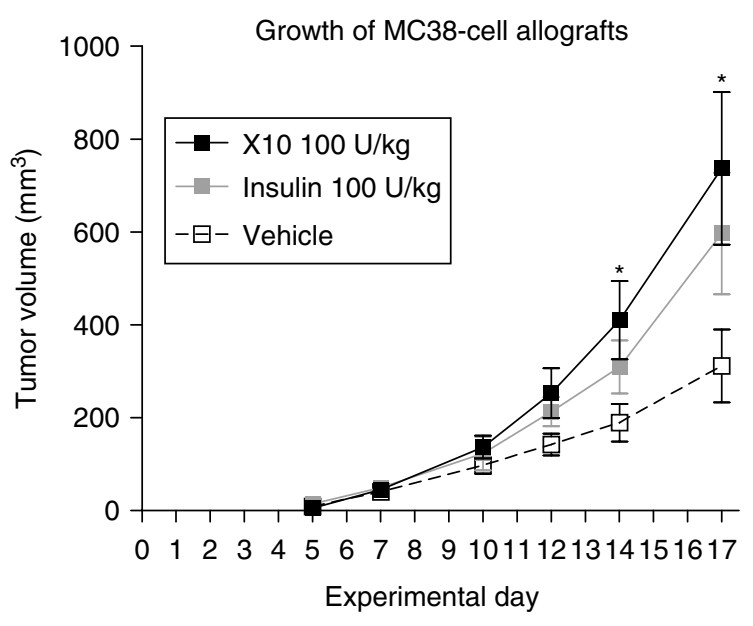

Figure 2 Mean volume of MC38 allografts. Tumors grew faster in animals treated with insulin and X10, and at experimental days 14 and 17 mean tumor volume was significantly increased in X10-treated animals compared with vehicle-treated animals. $n=6$, error bars $=$ S.E.M., ${ }^{*} P<0.05$. 

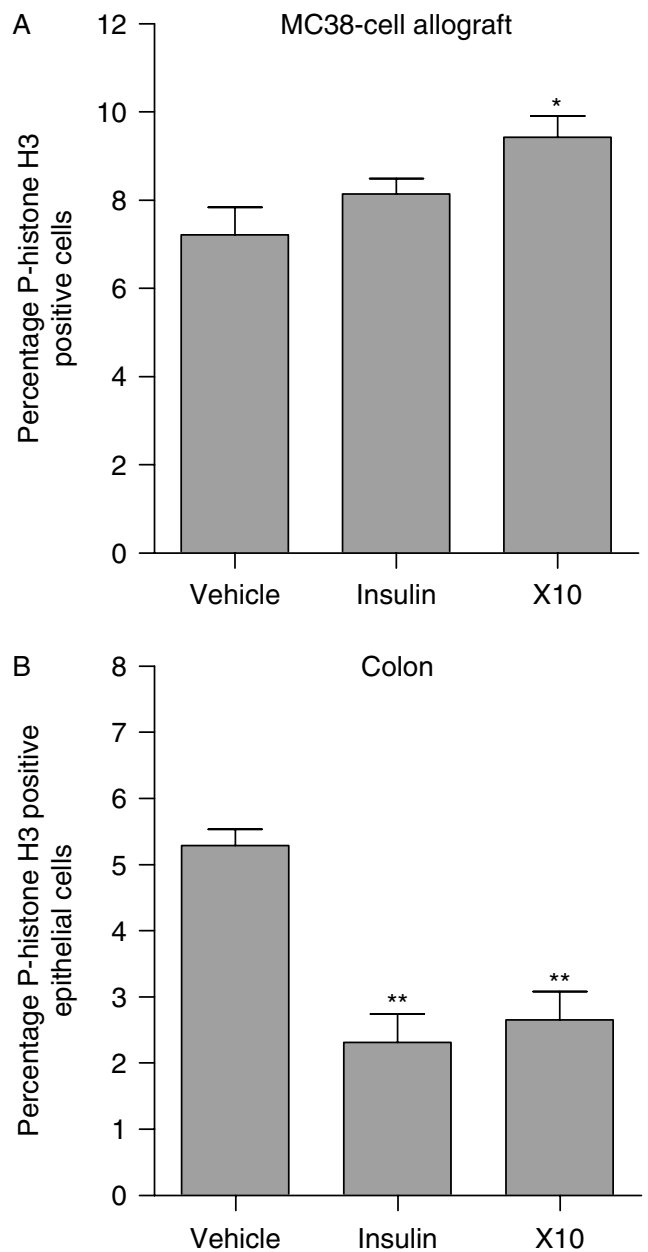

Figure 3 Mean percentage of cells stained for $\mathrm{P}-\mathrm{H} 3$ in MC38 cell allografts (A) and crypts of normal colon (B). The proliferation was significantly increased in MC38 cell allografts from animals treated with $\mathrm{X} 10(\mathrm{~A})$, whereas the proliferative activity of colon epithelial cells was significantly decreased in animals treated with insulin and $\mathrm{X} 10$ (B). $n=6$, error bars $=$ s.E.M., ${ }^{*} P<0.05$ and ${ }^{* *} P<0.001$.

insulin-treated animals, and 743 transcripts were significantly changed in tumors from animals treated with X10 (Fig. 4). Of these, 437 transcripts were identical. However, the change in expression for many of these transcripts was relatively small. Using $\geq 1.3$ or $\geq 1.5$-fold change in expression as cutoff values, as done in previous studies of gene expression (Peart et al. 2005, Huggins et al. 2008, Raouf et al. 2008), fewer transcripts were identified (Fig. 4). Interestingly, when using these cutoff values for detection of differentially regulated transcripts, X10 changed expression of more transcripts than insulin. When gene expression was compared directly between insulin- and X10-treated animals, 227 transcripts were expressed differently
(Fig. 4), and of these 31 transcripts displayed $\geq 1.3$ fold change in expression and only five transcripts displayed $\geq 1.5$-fold change.

Insulin and X10 influence expression of genes involved in amino acid and glucose metabolism, transmembrane transport, DNA replication, transcription, and RNA translation

Transcripts identified as differentially expressed using $\geq 1.5$-fold change could be grouped in six major categories (Table 1). Interestingly, of the 22 genes regulated by insulin, eight were related to metabolism and five were involved in DNA replication, RNA transcription, and RNA translation. Of the 62 genes regulated by X10, 17 were related to metabolism, three to transmembrane transport, and nine to DNA replication, RNA transcription, and RNA translation.

Functional analysis of annotated genes displaying $\geq 1.3$ - and $\geq 1$.5-fold change in expression with IPA is shown in Table 2. Top molecular and cellular functions were amino acid metabolism and small molecule biochemistry, which cover functions such as synthesis, transport, and metabolism of amino acids, synthesis of steroid and cholesterol, catabolism of ATP, and fatty acid metabolism (Table 2, Supplementary Tables 4 and 5, see section on supplementary data given at the end of this article). Top canonical pathways were glycine, serine, and threonine metabolism, alanine and aspartate metabolism, and aminoacyltRNA biosynthesis (Table 2). Functional analysis of annotated genes identified using all genes identified as differentially expressed (i.e. no cutoff value) and genes identified using $\geq 1.3$-fold expression difference as cutoff value resulted in identification of the same functions as the analysis done using the $\geq 1.5$-fold cutoff value. As described earlier, we focused on the genes and related functions, which displayed the largest fold changes, and selected a subset of these genes for further validation (Table 3).

Genes where expression was influenced differently by insulin and $X 10$ relate to functions such as metabolism, regulation of transcription, and cellular proliferation

Genes with a significant difference in expression between animals treated with insulin or X10 included genes related to metabolism (Aldh18al, Slcla4, and Atf4), transcription (Ddit3 and Trib3), and cell division (Plk2; Supplementary Table 6, see section on supplementary data given at the end of this article). Functional analysis of the genes where expression was influenced exclusively by insulin and not by X10 and 
ANOVA: Of 12390 detected transcripts, expression of 1056 was significantly changed.

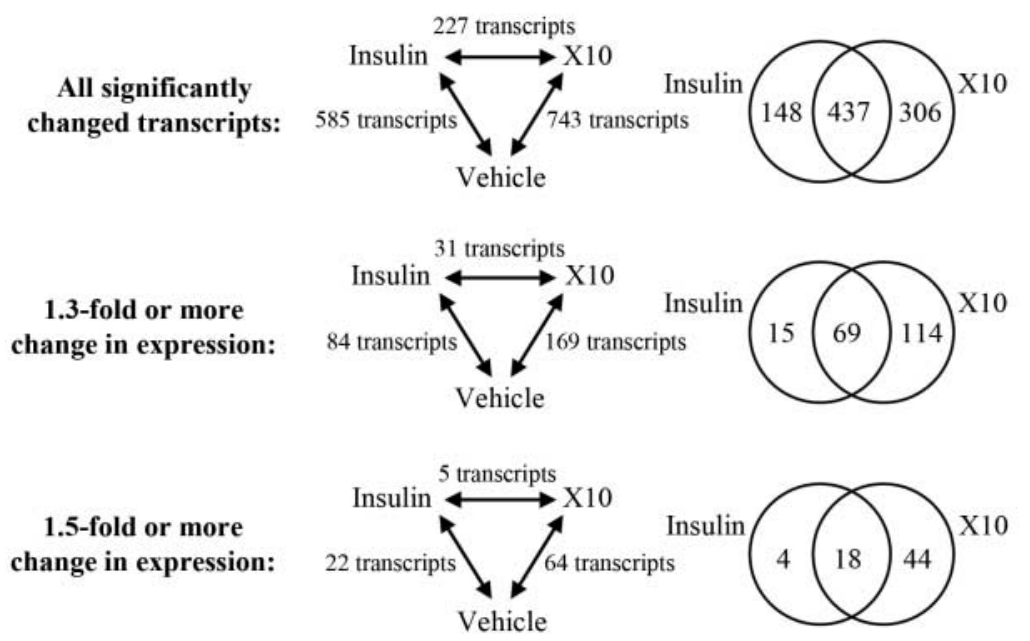

Figure 4 Transcripts with a significant difference in expression between animals treated with vehicle, insulin and X10 at different cutoff values for different expression. X10 influenced expression of more genes than insulin, and a considerable overlap was observed between genes whose expression changed after treatment with insulin or X10.

vice versa (the insulin- and X10-specific transcripts, respectively, shown by Venn diagrams in Fig. 4) revealed overlapping and similar functions: the top five functions for insulin-specific genes were cell death, growth and proliferation, cell cycle, small molecule biochemistry, and lipid metabolism. The top five functions for X10-specific genes were carbohydrate metabolism, small molecule biochemistry, cell compromise, cell morphology, and lipid metabolism (Supplementary Table 7, see section on supplementary data given at the end of this article).

\section{Confirmation of microarray results in vivo and in vitro using qRT-PCR}

Changes in the expression of 12 genes displaying the largest fold changes in expression and representing cellular functions identified in the functional analysis in the microarray study were confirmed using qRTPCR (Table 3). In the case of the pseudogene Loc100047619, which was identified as differentially expressed using microarrays, we examined expression of the homolog-coding gene Slc7a5 using qRT-PCR, as some pseudogenes are known to affect function of their homolog-coding genes (Poliseno et al. 2010). While Slc7a5 was not identified using microarray, qRT-PCR showed that the expression of this gene was increased (Table 3).

Expression of four genes representing the serine synthesis pathway, utilization of glutamine, glycolysis, and glucose uptake identified in the microarray study was also examined in vitro, where the expression was also significantly increased following treatment with insulin or X10 (Fig. 5).

\section{Insulin and X10 increase glucose contribution to serine synthesis}

To examine whether treatment with insulin or X10 also altered serine metabolism, we cultured MC38 cell in the presence of $\mathrm{U}_{-}{ }^{13} \mathrm{C}$ glucose and treated with vehicle, insulin, or X10. The resulting contribution of labeled glucose to serine and glycine was subsequently measured by gas chromatography and mass spectrometry. We found that treatment with insulin or X10 increased glucose contribution to the synthesis of serine and glycine with up to 40 and $35 \%$ respectively. This increase in serine and glycine synthesis was highly correlated, as expected in a linear pathway $(r=0.986, P<0.0001)$. In agreement with the greater effect on the mRNA expression levels after treatment with X10, X10 increased glucose contribution to serine synthesis at lower doses than insulin (Fig. 6).

\section{X10 and insulin increase expression of genes involved in cellular energy metabolism and nutrient uptake in colon cancer cells}

Using qRT-PCR, expression of eight genes involved in the serine synthesis pathway, glutamine utilization, amino acid, and glucose uptake was examined in normal colon from the animals treated with insulin or X10 (Table 3). While expression of these genes was 

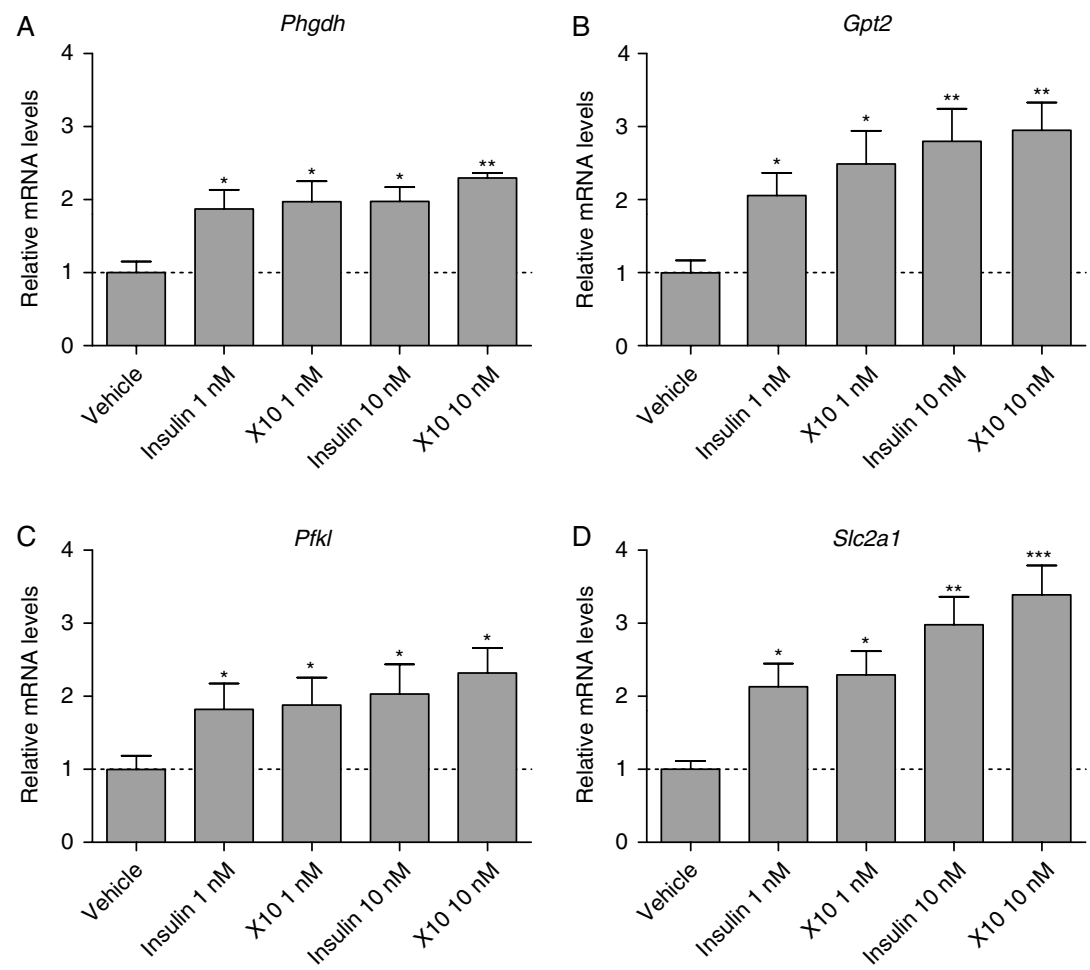

Figure 5 Insulin and X10 increased expressions of Phgdh (A), Gpt2 (B), Pfkl(C), and Slc2a1 (D) in MC38 cells in vitro. Bars indicated the mean relative expression of each gene calculated from three independent experiments, with three replicates per condition. Error bars $=$ S.E.M., ${ }^{\star} P<0.05,{ }^{\star \star} P<0.001$, and ${ }^{\star \star *} P<0.0001$.

increased in the tumor allografts following treatment with insulin or X10, no significant changes in expression were observed in normal colon (Table 3), suggesting that insulin and X10 regulate gene expression differently in transformed and nontransformed cells.

Expression of key genes involved in metabolism and nutrient uptake also differed significantly when tumor allografts and normal colon from vehicle-treated animals was compared. Expression of Phgdh, Psatl, and Shmt2 (serine synthesis pathway), Asns (glutamine utilization), Slc7a5 (transport of amino acids across plasma membrane), and Slc25a33 (transport of metabolites and precursors across mitochondrial membrane) was significantly increased, whereas expression of Slc2al (glucose uptake) and $P f k l$ (glycolysis) was significantly decreased (Fig. 7). Decreased expression of the glucose transporter Slc2al and the glycolytic enzyme Pfkl in the MC38 allografts can seem surprising, but a recent study reported that $S L C 2 A 1$ and another glycolytic enzyme $(H K 2)$ were also expressed at decreased levels in normal colon mucosa from patients with colon cancer compared with normal colon mucosa from individuals without colon cancer (Silviera et al. 2012).
Insulin and X10 have minor effects on the expression of genes involved in MAPK-signaling and cell cycle regulation in MC38 allografts

In the functional analysis of transcripts responsive to insulin and/or X10, ERK5 and MAPK/ERK signaling were among the identified canonical pathways. The regulated genes linked to these pathways and mean fold changes are listed in Supplementary Table 8, see section on supplementary data given at the end of this article. Expression of some of these genes was increased while expression of other genes encoding enzymes with similar functions was decreased, and changes in expression were small (on average: 1.2 -fold change), which argue against an important effect of insulin and X10 on these pathways.

Expression of Ccng2, an inhibitory cyclin which block cell cycle entry and proliferation (Horne et al. 1997), which was previously reported to decrease following treatment with insulin (Jensen et al. 2008), was detected in the MC38 allografts, but expression was not changed in insulin- or X10-treated animals relative to vehicle-treated (Table 3). Expression of Ccng2 was also unchanged in normal colon. However, compared with normal colon, Ccng2 was expressed at significantly lower levels in MC38 allografts (Fig. 7), 

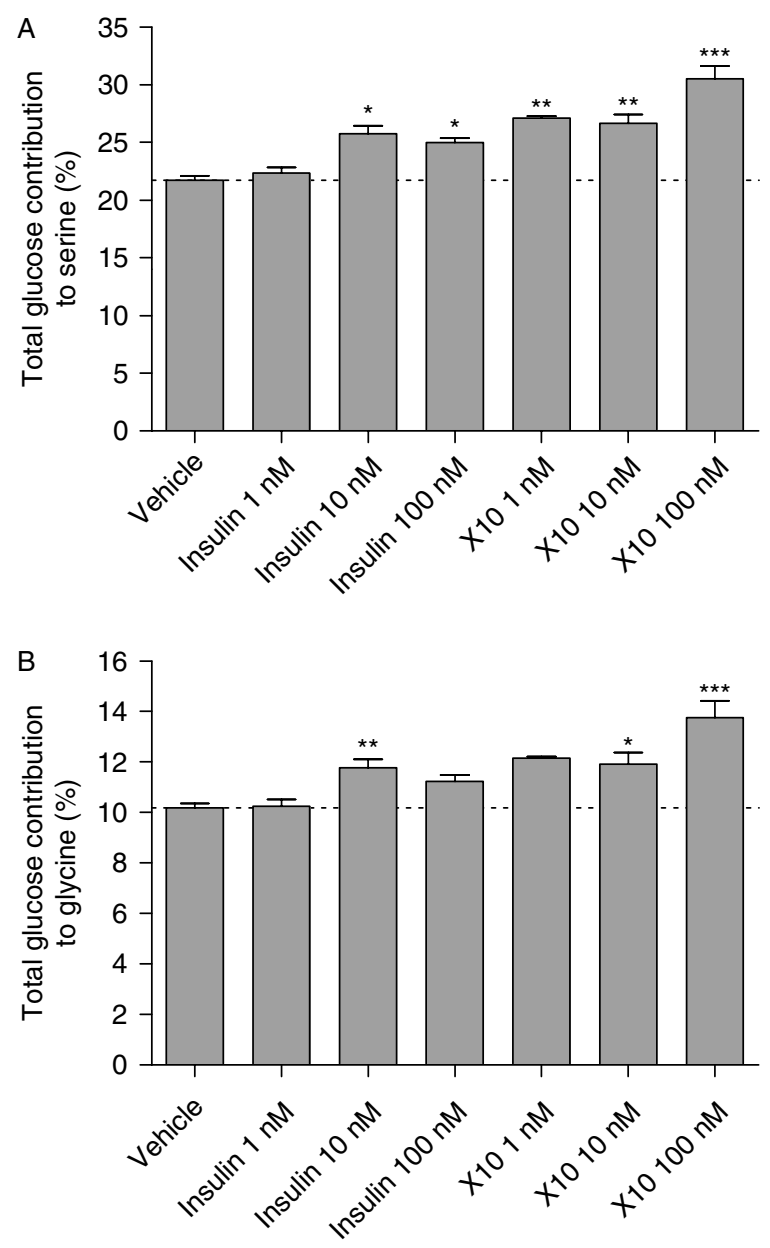

Figure 6 Mean total glucose contribution to serine and glycine increases after treatment with insulin or X10. MC38 were cultured in $\mathrm{U}-{ }^{13} \mathrm{C}$ glucose. Labeling patterns in serine $(\mathrm{A})$ and glycine $(B)$ were measured with gas chromatography and mass spectrometry. Error bar $=$ S.D., ${ }^{\star} P<0.05,{ }^{\star \star} P<0.001$, and ${ }^{* * *} P<0.0001$.

and one could speculate that $C c n g 2$ is therefore already expressed at sufficiently low levels for tumor proliferation, making further downregulation unnecessary.

\section{Discussion}

This is the first study to examine the effects of administration of insulin X10 and human insulin on global gene expression in an insulin-sensitive tumor in vivo. We show that growth stimulatory effects are associated with increased expression of genes involved in metabolism, uptake of amino acids, translation and protein synthesis, and the serine synthesis pathway, and that treatment with insulin or X10 results in increased contribution of glucose to serine synthesis.

Cutoff values for the definition of differently expressed genes in studies of changes in global gene expression are all somewhat arbitrary, as the minimum change in mRNA expression that will result in a biological effect is unknown. However, in this study we used cutoff values for the definition of differentially expressed genes which have been used in previous studies (Peart et al. 2005, Huggins et al. 2008, Raouf et al. 2008) and furthermore performed functional analysis of differently expressed genes using different cutoff values, as described earlier. As expected, these functional analyses did not yield completely identical results but consistently showed that functions and canonical pathways listed in Table 2 were represented and that genes listed in Table 3 displayed the largest fold changes in expression in response to treatment with insulin or X10. We are therefore confident that our analytical approach allowed identification of major and true effects of insulin and X10 on gene expression in this in vivo model of colon cancer.

A recent study demonstrated that the expression of Phgdh and Shmt2 and other members of the serine synthesis pathway is regulated by the transcription factor Myc (Vazquez et al. 2011), which is known to be responsive to insulin (Kaburagi et al. 2004). Another previous study reported that insulin in mouse embryonic fibroblasts, via the transcription factor Atf4, increased the expression of Phgdh, Psat1, Shmt2, and Asns and the amino acid transporters Slcla4 and Slc7a5 (discussed further below), and other genes involved in protein anabolism (Adams 2007). Increased expression and/or activity of enzymes in the serine synthesis pathway has also previously been documented in various human cancers, including colon carcinoma (Snell et al. 1988, Cho et al. 2000) and recent studies found that the expression of Phgdh is

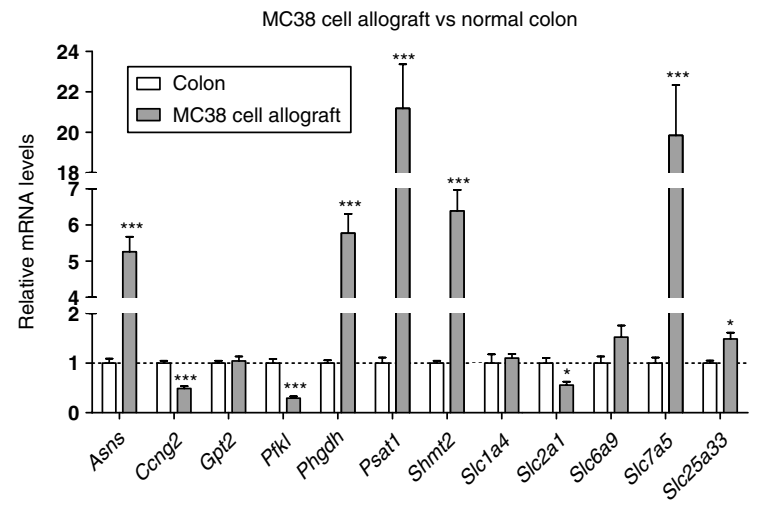

Figure 7 Mean expression of selected genes in MC38 allografts relative to normal colon in vehicle-treated animals. Expression of several genes varied significantly between MC38 allografts and normal colon. Expression levels of different genes cannot be compared. $n=6$, error bars $=$ S.E.M., ${ }^{*} P<0.05$ and ${ }^{\star \star \star} P<0.0001$. 
frequently increased in aggressive breast cancers (Possemato et al. 2011) and melanoma (Locasale et al. 2011). These studies furthermore showed that the introduction of ectopic expression of Phgdh in mammary epithelial cells resulted in disruption of normal acinar morphology and apical polarity (Locasale et al. 2011). Increased generation of serine in cancer cells can be used for increased synthesis of nucleic acids, lipids, and protein, but Possemato et al. (2011) showed that generation of $\alpha$-ketoglutarate $(\alpha \mathrm{KG})$ from glutamine (catalyzed by PSAT1 in the second step of the serine synthesis pathway) is another important effect of the increased activity of this pathway. Proliferating cells use intermediary metabolites from the tricarboxylic acid cycle (TCA) for the synthesis of proteins, nucleotides, and lipids and increasing the synthesis of $\alpha \mathrm{KG}$ is one way to replenish the efflux of TCA metabolites (DeBerardinis et al. 2007). Possemato et al. (2011) showed that in breast cancers with high expression of Phgdh, the serine synthesis pathway contributed with $\sim 50 \%$ of flux of glutamate to $\alpha \mathrm{KG}$. Other enzymes that contribute to the generation of $\alpha \mathrm{KG}$, although to a lower extent, are ASNS (glutamine to glutamate) and GPT2 (glutamate to $\alpha \mathrm{KG}$; Yang et al. 2002, DeBerardinis et al. 2007, Possemato et al. 2011). It is therefore highly interesting that we in our in vivo model of colon cancer find i) that increased expression of Phgdh, Psat1, Shmt2, and Asns compared with normal colon, ii) that treatment with insulin and X10 results in increased tumor growth and further increased the expression of Phgdh, Psatl, and Shmt2, and iii) that the increased expression of genes in the serine synthesis pathway is correlated with increased glucose contribution to serine and glycine syntheses in MC38 cells.

Treatment with insulin and X10 also increased the expression of genes encoding amino acid transporters: Slc1a4 (uptake of alanine, serine, cystein, and threonin), Slc6a9 (uptake of glycine), and Slc7a5 (uptake of phenylalanine, tyrosine, leucine, arginine, and tryptophan in exchange for glutamine). These transporters have previously been reported to be expressed in normal intestinal epithelial cells, colon cancer, and various cancer cell lines (Yanagida et al. 2001, Fuchs \& Bode 2005, Broer 2008, Howard \& Hirst 2011). Amino acids can be utilized in cancer cell for synthesis of protein and other macromolecules. In this context, it is interesting that expression of several genes encoding aminoacyl-tRNA synthetases was also increased by insulin and X10 (at $\geq 1.5$-fold change cut off: Lars, Nars, and Sars). These enzymes link amino acids to their cognate tRNA that is necessary for translation of mRNA into protein (Cusack 1997).
In total, expression of 11 genes encoding aminoacyltRNA synthetases was increased significantly by insulin and X10, and although the fold changes in expression were moderate (1.16- to 1.65 -fold increased), this suggests that effects of insulin and $\mathrm{X} 10$ on translation and protein synthesis in cancer cells are important. This finding is consistent with a previous study showing strong activation of p70S6 kinase, S6 ribosomal protein, and 4E-BP1, all involved in translation and protein synthesis, acutely following treatment of cancer cells with insulin or X10 (Oleksiewicz et al. 2011).

Expression of Slc25a33 (mitochondrial pyrimidine nucleotide carrier 1) has previously been reported to be stimulated by insulin and IGF1 and also to be increased in neoplastic cells (Floyd et al. 2007). The gene encodes a mitochondrial pyrimidine nucleotide carrier, which is known to mediate uptake of predominantly UTP but also GTP, CTP, and TTP (Floyd et al. 2007). Slc25a33-mediated uptake of UTP is important for transcription and replication of mitochondrial DNA, which again is important for mitochondrial function, i.e. increased expression of Slc25a33 enables a cancer cell to optimally produce ATP and grow while it also protects the cell from metabolic stress by preventing increased production of reactive oxygen species (Favre et al. 2010). This is therefore another effect of insulin and X10 that provides cancer cells with a growth advantage.

Expression of genes Slc2al (glucose transporter 1), $P f k l$, and $H k 2$ (glycolytic enzymes) were also increased following treatment with insulin or X10 (Tables 1 and 3). Although the microarray data suggested that the expressions of $S l c 2 a l$ and $P f k l$ were only responsive to insulin, we observed increased expression of both genes after treatment with insulin and X10 when measured by qRT-PCR, although this for $P f k l$ was only significant in vitro (Fig. 5). Previous studies have reported increased expression of $S l c 2 a l$ after treatment with insulin (Jensen et al. 2008), and expression of Slc2al has been demonstrated in several different human cancers (Younes et al. 1996). A recent study showed hyperinsulinemia was associated with increased glucose uptake in tumor cells in vivo (Mashhedi et al. 2011), and the observed effect on Slc2al is therefore biological plausible. Cancer cells are characterized by increased glycolysis (the Warburg effect), and increased expression of $P f k l$ and activity of PFKL as well as other glycolytic enzymes are well known in proliferating cells and cancer cells (Vora et al. 1985, Brand et al. 1988, Greiner et al. 1994). However, at the last step of glycolysis most cancer cells paradoxically express the less active M2 isoform 
of pyruvate kinase (PKM2). Interestingly, a recent study demonstrated that the lower activity of PKM2 leads to accumulation of glycolytic intermediates, which are then available for serine synthesis (Ye et al. 2012).

In our study, we included the insulin analog X10, which was developed as a rapid-acting insulin analog, by replacement of histidine at position 10 in the B-chain with aspartic acid (Brange et al. 1988). This single amino acid substitution led to increased affinity to the IR and the closely related IGF1R and decreased off-rate from the IR (Hansen et al. 1996, Slieker et al. 1997, Kurtzhals et al. 2000). Previous studies found that the mitogenic potential of X10 was 3- to 15-fold higher than native insulin in vitro (Gammeltoft et al. 1999, Kurtzhals et al. 2000), and supra-pharmacological doses of X10 increased the incidence of spontaneous mammary tumors in female SpragueDawley rats (Dideriksen et al. 1992). Further development of X10 for clinical use was therefore discontinued due to cancer concerns.

We observed differences in the number of genes affected by insulin and X10 and were also able to identify sets of genes where expression was influenced exclusively by insulin or X10. Functional analysis of genes with significantly different expression and genes regulated exclusively by insulin or X10 revealed that both insulin- and X10-specific genes were involved in many of the same molecular and cellular functions. Furthermore, X10 was a more potent regulator of gene expression than insulin for the majority of examined genes, but this was statistically significant for only a few genes (e.g. Atf4, Slcla4, and Trib3). However, this somewhat subtle difference between insulin and X10 in gene expression is in good agreement with the tumor growth and proliferation data, where a trend but no significant difference was observed.

In conclusion, we demonstrate that doses of X10 previously shown to be carcinogenic in rats stimulate growth of a murine colon cancer allograft, and that treatment with insulin and X10 increases expression in neoplastic tissue of genes encoding several key enzymes involved in the serine synthesis pathway, utilization of glutamine and glycolysis as well as genes encoding amino acid transporters. The insulin- and X10-stimulated increase in the expression of genes in the serine synthesis pathway leads to specific changes in metabolic flux recently shown to favor neoplastic growth. Thus, our results reveal that the effect of insulin and insulin analogs in stimulating proliferation of experimental cancers involves a previously unrecognized effect on carbon flux through the serine synthesis pathway.

\section{Supplementary data}

This is linked to the online version of the paper at http://dx. doi.org/10.1530/ERC-12-0125.

\section{Declaration of interest}

H Hvid, A M Svendsen and B F Hansen are employed by Novo Nordisk A/S. M Pollak has consulted for Novo Nordisk A/S. The remaining authors declare no conflict of interests.

\section{Funding}

This study was supported by Novo Nordisk A/S and by a grant (TFF-116128) from the Canadian Institute of Health Research. S-M Fendt is supported by the German Research Foundation.

\section{References}

Adami HO, McLaughlin J, Ekbom A, Berne C, Silverman D, Hacker D \& Persson I 1991 Cancer risk in patients with diabetes mellitus. Cancer Causes \& Control 2 307-314. (doi:10.1007/BF00051670)

Adams CM 2007 Role of the transcription factor ATF4 in the anabolic actions of insulin and the anti-anabolic actions of glucocorticoids. Journal of Biological Chemistry 282 16744-16753. (doi:10.1074/jbc.M610510200)

Antoniewicz MR, Kelleher JK \& Stephanopoulos G 2007 Elementary metabolite units (EMU): a novel framework for modeling isotopic distributions. Metabolic Engineering 9 68-86. (doi:10.1016/j.ymben.2006.09.001)

Baldi P \& Long AD 2001 A Bayesian framework for the analysis of microarray expression data: regularized $t$-test and statistical inferences of gene changes. Bioinformatics 17 509-519. (doi:10.1093/bioinformatics/17.6.509)

Benjamini Y \& Hochberg Y 1995 Controlling the false discovery rate: a practical and powerful approach to multiple testing. Journal of the Royal Statistical Society: Series B 57 289-300.

Bibby BM, Martinussen T \& Skovgaard IM 2004 Experimental Design in the Agricultural Sciences, 1st edn. Copenhagen, Denmark: Samfundslitteratur.

Brand K, Aichinger S, Forster S, Kupper S, Neumann B, Nurnberg W \& Ohrisch G 1988 Cell-cycle-related metabolic and enzymatic events in proliferating rat thymocytes. European Journal of Biochemistry 172 695-702. (doi:10.1111/j.1432-1033.1988.tb13944.x)

Brange J, Ribel U, Hansen JF, Dodson G, Hansen MT, Havelund S, Melberg SG, Norris F, Norris K, Snel L et al. 1988 Monomeric insulins obtained by protein engineering and their medical implications. Nature 333 679-682. (doi:10.1038/333679a0)

Broer S 2008 Amino acid transport across mammalian intestinal and renal epithelia. Physiological Reviews $\mathbf{8 8}$ 249-286. (doi:10.1152/physrev.00018.2006) 
Calle EE \& Kaaks R 2004 Overweight, obesity and cancer: epidemiological evidence and proposed mechanisms. Nature Reviews. Cancer 4 579-591. (doi:10.1038/nrc1408)

Carstensen B, Witte DR \& Friis S 2012 Cancer occurrence in Danish diabetic patients: duration and insulin effects. Diabetologia 55 948-958. (doi:10.1007/s00125-011-2381-4)

Chen J 2011 Multiple signal pathways in obesity-associated cancer. Obesity Reviews 12 1063-1070. (doi:10.1111/ j.1467-789X.2011.00917.x)

Cho HM, Jun DY, Bae MA, Ahn JD \& Kim YH 2000 Nucleotide sequence and differential expression of the human 3-phosphoglycerate dehydrogenase gene. Gene 245 193-201. (doi:10.1016/S0378-1119(00)00009-3)

Coughlin SS, Calle EE, Teras LR, Petrelli J \& Thun MJ 2004 Diabetes mellitus as a predictor of cancer mortality in a large cohort of US adults. American Journal of Epidemiology 159 1160-1167. (doi:10.1093/aje/kwh161)

Cusack S 1997 Aminoacyl-tRNA synthetases. Current Opinion in Structural Biology 7 881-889. (doi:10.1016/ S0959-440X(97)80161-3)

DeBerardinis RJ, Mancuso A, Daikhin E, Nissim I, Yudkoff M, Wehrli S \& Thompson CB 2007 Beyond aerobic glycolysis: transformed cells can engage in glutamine metabolism that exceeds the requirement for protein and nucleotide synthesis. PNAS 104 19345-19350. (doi:10.1073/pnas. 0709747104)

Dideriksen LH, Jørgensen LN \& Dreijer K 1992 Carcinogenic effects on female rats after 12 months administration of insulin analogue b10 asp. Diabetes 41 143A.

Du P, Kibbe WA \& Lin SM 2008 lumi: a pipeline for processing Illumina microarray. Bioinformatics $\mathbf{2 4}$ 1547-1548. (doi:10.1093/bioinformatics/btn224)

Favre C, Zhdanov A, Leahy M, Papkovsky D \& O'Connor R 2010 Mitochondrial pyrimidine nucleotide carrier (PNC1) regulates mitochondrial biogenesis and the invasive phenotype of cancer cells. Oncogene 29 3964-3976. (doi:10.1038/onc.2010.146)

Floyd S, Favre C, Lasorsa FM, Leahy M, Trigiante G, Stroebel P, Marx A, Loughran G, O'Callaghan K, Marobbio CM et al. 2007 The insulin-like growth factor-I-mTOR signaling pathway induces the mitochondrial pyrimidine nucleotide carrier to promote cell growth. Molecular Biology of the Cell 18 3545-3555. (doi:10.1091/mbc.E06-12-1109)

Fuchs BC \& Bode BP 2005 Amino acid transporters ASCT2 and LAT1 in cancer: partners in crime? Seminars in Cancer Biology 15 254-266. (doi:10.1016/j.semcancer. 2005.04.005)

Gammeltoft S, Hansen BF, Dideriksen L, Lindholm A, Schaffer L, Trub T, Dayan A \& Kurtzhals P 1999 Insulin aspart: a novel rapid-acting human insulin analogue. Expert Opinion on Investigational Drugs 8 1431-1442. (doi:10.1517/13543784.8.9.1431)

Greiner EF, Guppy M \& Brand K 1994 Glucose is essential for proliferation and the glycolytic enzyme induction that provokes a transition to glycolytic energy production. Journal of Biological Chemistry 269 31484-31490.
Gundersen HJ, Bagger P, Bendtsen TF, Evans SM, Korbo L, Marcussen N, Moller A, Nielsen K, Nyengaard JR, Pakkenberg B et al. 1988 The new stereological tools: disector, fractionator, nucleator and point sampled intercepts and their use in pathological research and diagnosis. APMIS: Acta Pathologica, Microbiologica et Immunologica Scandinavica 96 857-881. (doi:10.1111/j. 1699-0463.1988.tb00954.x)

Hansen BF, Danielsen GM, Drejer K, Sorensen AR, Wiberg FC, Klein HH \& Lundemose AG 1996 Sustained signalling from the insulin receptor after stimulation with insulin analogues exhibiting increased mitogenic potency. Biochemical Journal 315 271-279.

Horne MC, Donaldson KL, Goolsby GL, Tran D, Mulheisen M, Hell JW \& Wahl AF 1997 Cyclin G2 is up-regulated during growth inhibition and B cell antigen receptor-mediated cell cycle arrest. Journal of Biological Chemistry 272 12650-12661. (doi:10.1074/jbc.272.19. 12650)

Howard A \& Hirst BH 2011 The glycine transporter GLYT1 in human intestine: expression and function. Biological \& Pharmaceutical Bulletin 34 784-788. (doi:10.1248/bpb. 34.784)

Huggins CE, Domenighetti AA, Ritchie ME, Khalil N, Favaloro JM, Proietto J, Smyth GK, Pepe S \& Delbridge LM 2008 Functional and metabolic remodelling in GLUT4-deficient hearts confers hyper-responsiveness to substrate intervention. Journal of Molecular and Cellular Cardiology 44 270-280. (doi:10.1016/j.yjmcc. 2007.11.020)

Hvid H, Klopfleisch R, Vienberg S, Hansen BF, Thorup I, Jensen HE \& Oleksiewicz MB 2011 Unique expression pattern of the three insulin receptor family members in the rat mammary gland: dominance of IGF-1R and IRR over the IR, and cyclical IGF-1R expression. Journal of Applied Toxicology 31 312-328. (doi:10.1002/jat.1627)

Jensen M \& De Meyts P 2009 Molecular mechanisms of differential intracellular signaling from the insulin receptor. Vitamins and Hormones 80 51-75. (doi:10.1016/s0083-6729(08)00603-1)

Jensen M, Hansen B, DeMeyts P, Schaffer L \& Urso B 2007 Activation of the insulin receptor by insulin and a synthetic peptide leads to divergent metabolic and mitogenic signaling and responses. Journal of Biological Chemistry 282 35179-35186. (doi:10.1074/jbc. M704599200)

Jensen M, Palsgaard J, Borup R, De Meyts P \& Schaffer L 2008 Activation of the insulin receptor (IR) by insulin and a synthetic peptide has different effects on gene expression in IR-transfected L6 myoblasts. Biochemical Journal 412 435-445. (doi:10.1042/BJ20080279)

Kaburagi Y, Yamashita R, Ito Y, Okochi H, Yamamoto-Honda R, Yasuda K, Sekihara H, Sasazuki T, Kadowaki T \& Yazaki Y 2004 Insulin-induced cell cycle progression is impaired in chinese hamster ovary cells overexpressing insulin receptor substrate-3. Endocrinology 145 5862-5874. (doi:10.1210/en.2004-0199) 
Kurtzhals P, Schaffer L, Sorensen A, Kristensen C, Jonassen I, Schmid C \& Trub T 2000 Correlations of receptor binding and metabolic and mitogenic potencies of insulin analogs designed for clinical use. Diabetes 49 999-1005. (doi:10.2337/diabetes.49.6.999)

Lawlor MA \& Alessi DR 2001 PKB/Akt: a key mediator of cell proliferation, survival and insulin responses? Journal of Cell Science 114 2903-2910.

Lin SM, Du P, Huber W \& Kibbe WA 2008 Model-based variance-stabilizing transformation for Illumina microarray data. Nucleic Acids Research 36 e11. (doi:10.1093/ nar/gkm1075)

Listov-Saabye N, Jensen MB, Kiehr B, Hansen EW, Svendsen JE, Lundby A, Holm GM \& Oleksiewicz MB 2009 MCF-7 human mammary adenocarcinoma cells exhibit augmented responses to human insulin on a collagen IV surface. Journal of Applied Toxicology 29 470-477. (doi:10.1002/jat.1428)

Locasale JW, Grassian AR, Melman T, Lyssiotis CA, Mattaini KR, Bass AJ, Heffron G, Metallo CM, Muranen T, Sharfi H et al. 2011 Phosphoglycerate dehydrogenase diverts glycolytic flux and contributes to oncogenesis. Nature Genetics 43 869-874. (doi:10.1038/ng.890)

Lundby C, Nordsborg N, Kusuhara K, Kristensen KM, Neufer PD \& Pilegaard H 2005 Gene expression in human skeletal muscle: alternative normalization method and effect of repeated biopsies. European Journal of Applied Physiology 95 351-360. (doi:10.1007/s00421005-0022-7)

Mashhedi H, Blouin MJ, Zakikhani M, David S, Zhao Y, Bazile M, Birman E, Algire C, Aliaga A, Bedell BJ et al. 2011 Metformin abolishes increased tumor (18)F-2fluoro-2-deoxy-D-glucose uptake associated with a high energy diet. Cell Cycle 10 2770-2778. (doi:10.4161/cc. 10.16.16219)

Milazzo G, Sciacca L, Papa V, Goldfine ID \& Vigneri R 1997 ASPB10 insulin induction of increased mitogenic responses and phenotypic changes in human breast epithelial cells: evidence for enhanced interactions with the insulin-like growth factor-I receptor. Molecular Carcinogenesis 18 19-25. (doi:10.1002/(SICI)10982744(199701)18:1 < 19::AID-MC3 > 3.0.CO;2-M)

Nanchen A, Fuhrer T \& Sauer U 2007 Determination of metabolic flux ratios from ${ }^{13} \mathrm{C}$-experiments and gas chromatography-mass spectrometry data: protocol and principles. Methods in Molecular Biology 358 177-197. (doi:10.1007/978-1-59745-244-1_11)

O’Brien RM \& Granner DK 1996 Regulation of gene expression by insulin. Physiological Reviews $\mathbf{7 6}$ 1109-1161.

Ogunleye AA, Ogston SA, Morris AD \& Evans JM 2009 A cohort study of the risk of cancer associated with type 2 diabetes. British Journal of Cancer 101 1199-1201. (doi:10.1038/sj.bjc.6605240)

Oleksiewicz MB, Bonnesen C, Hegelund AC, Lundby A, Holm GM, Jensen MB \& Krabbe JS 2011 Comparison of intracellular signalling by insulin and the hypermitogenic
AspB10 analogue in MCF-7 breast adenocarcinoma cells. Journal of Applied Toxicology 31 329-341. (doi:10.1002/ jat.1590)

Peart MJ, Smyth GK, van Laar RK, Bowtell DD, Richon VM, Marks PA, Holloway AJ \& Johnstone RW 2005 Identification and functional significance of genes regulated by structurally different histone deacetylase inhibitors. PNAS 102 3697-3702. (doi:10.1073/pnas. 0500369102)

Poliseno L, Salmena L, Zhang J, Carver B, Haveman WJ \& Pandolfi PP 2010 A coding-independent function of gene and pseudogene mRNAs regulates tumour biology. Nature 465 1033-1038. (doi:10.1038/ nature09144)

Possemato R, Marks KM, Shaul YD, Pacold ME, Kim D, Birsoy K, Sethumadhavan S, Woo HK, Jang HG, Jha AK et al. 2011 Functional genomics reveal that the serine synthesis pathway is essential in breast cancer. Nature 476 346-350. (doi:10.1038/nature10350)

Raouf A, Zhao Y, To K, Stingl J, Delaney A, Barbara M, Iscove N, Jones S, McKinney S, Emerman J et al. 2008 Transcriptome analysis of the normal human mammary cell commitment and differentiation process. Cell Stem Cell 3 109-118. (doi:10.1016/j.stem.2008.05.018)

Saltiel AR \& Kahn CR 2001 Insulin signalling and the regulation of glucose and lipid metabolism. Nature $\mathbf{4 1 4}$ 799-806. (doi:10.1038/414799a)

Sciacca L, Cassarino MF, Genua M, Pandini G, Le MR, Squatrito S \& Vigneri R 2010 Insulin analogues differently activate insulin receptor isoforms and postreceptor signalling. Diabetologia 53 1743-1753. (doi:10.1007/s00125-010-1760-6)

Silviera ML, Smith BP, Powell J \& Sapienza C 2012 Epigenetic differences in normal colon mucosa of cancer patients suggest altered dietary metabolic pathways. Cancer Prevention Research 5 374-384. (doi:10.1158/ 1940-6207.CAPR-11-0336)

Slieker LJ, Brooke GS, DiMarchi RD, Flora DB, Green LK, Hoffmann JA, Long HB, Fan L, Shields JE, Sundell KL et al. 1997 Modifications in the B10 and B26-30 regions of the B chain of human insulin alter affinity for the human IGF-I receptor more than for the insulin receptor. Diabetologia 40 (Suppl 2) S54-S61. (doi:10.1007/ s001250051402)

Smith U \& Gale EA 2009 Does diabetes therapy influence the risk of cancer? Diabetologia 52 1699-1708. (doi:10.1007/ s00125-009-1441-5)

Snell K, Natsumeda Y, Eble JN, Glover JL \& Weber G 1988 Enzymic imbalance in serine metabolism in human colon carcinoma and rat sarcoma. British Journal of Cancer $\mathbf{5 7}$ 87-90. (doi:10.1038/bjc.1988.15)

Sommerfeld MR, Muller G, Tschank G, Seipke G, Habermann P, Kurrle R \& Tennagels N 2010 In vitro metabolic and mitogenic signaling of insulin glargine and its metabolites. PLOS ONE 5 e9540. (doi:10.1371/journal. pone.0009540) 
Vander Heiden MG, Cantley LC \& Thompson CB 2009 Understanding the Warburg effect: the metabolic requirements of cell proliferation. Science 324 1029-1033. (doi:10.1126/science.1160809)

Vazquez A, Markert EK \& Oltvai ZN 2011 Serine biosynthesis with one carbon catabolism and the glycine cleavage system represents a novel pathway for ATP generation. PLOS ONE 6 e25881. (doi:10.1371/journal. pone.0025881)

Vora S, Halper JP \& Knowles DM 1985 Alterations in the activity and isozymic profile of human phosphofructokinase during malignant transformation in vivo and in vitro: transformation- and progression-linked discriminants of malignancy. Cancer Research 45 2993-3001.

Yanagida O, Kanai Y, Chairoungdua A, Kim DK, Segawa H, Nii T, Cha SH, Matsuo H, Fukushima J, Fukasawa Y et al. 2001 Human L-type amino acid transporter 1 (LAT1): characterization of function and expression in tumor cell lines. Biochimica et Biophysica Acta 1514 291-302. (doi:10.1016/S0005-2736(01)00384-4)
Yang RZ, Blaileanu G, Hansen BC, Shuldiner AR \& Gong DW 2002 cDNA cloning, genomic structure, chromosomal mapping, and functional expression of a novel human alanine aminotransferase. Genomics 79 445-450. (doi:10.1006/geno.2002.6722)

Ye J, Mancuso A, Tong X, Ward PS, Fan J, Rabinowitz JD \& Thompson CB 2012 Pyruvate kinase M2 promotes de novo serine synthesis to sustain mTORC1 activity and cell proliferation. PNAS 109 6904-6909. (doi:10.1073/ pnas.1204176109)

Younes M, Lechago LV, Somoano JR, Mosharaf M \& Lechago J 1996 Wide expression of the human erythrocyte glucose transporter Glut1 in human cancers. Cancer Research 56 1164-1167.

Received in final form 29 May 2012

Accepted 7 June 2012

Made available online as an Accepted Preprint 8 June 2012 